\title{
Chemical composition, functional and biscuit making properties of tomato peel flour
}

\author{
Peter Isah Akubor* and Abubakar Usman Owuse
}

Department of Food Science Technology, Federal University Wukari, Taraba State, Nigeria

*Email: akuborpeter@gmail.com

\begin{abstract}
The study investigated the quality of biscuit supplemented with ripe tomato peel flour. Ripe tomato fruits were peeled manually and the peels were used to prepare flour. The flour was used to substitute 10, 20 and $30 \%$ of wheat flour. The flours were analyzed for the chemical composition and functional properties. The flour blends were used to prepare biscuits which were evaluated for the chemical composition, physical and sensory properties. The wheat flour had significantly $(\mathrm{p}<0.05)$ higher water absorption capacity, oil absorption capacity, swelling capacity but lower bulk density than the tomato peel flour. However, the tomato peel flour contained higher amounts of flavonoids, phenol and carotenoids than the wheat flour and the biscuit. The flavonoids, phenols and carotenoids contents of the wheat flour were $1.20,4.40$ and $0.48 \mathrm{mg} / 100 \mathrm{~g}$, respectively while those of the biscuits were 211.35 , 123.39 and $12.5 \mathrm{mg} / 100 \mathrm{~g}$, respectively. The tomato peel flour contained significantly $(\mathrm{p}<0.05)$ higher amounts of ash, fat, protein and crude fiber but lower carbohydrate content than the wheat flour. The total dietary fiber (TDF), insoluble dietary fiber (IDF) and soluble dietary fiber (SDF) contents of tomato peel flour were $85.56,70.25$ and $15.31 \%$, respectively while those of wheat flour were $34.80,23.35$ and $11.45 \%$, respectively. The TDF, IDF and SDF contents increased to 71.03, 58.94 and $13.07 \%$ respectively in the biscuits relative to those of wheat flour. The $\mathrm{Na}, \mathrm{K}, \mathrm{Ca}, \mathrm{Mg}, \mathrm{Fe}$ and $\mathrm{Zn}$ contents of the tomato peel flour were higher than those of the wheat flour and the biscuit. The levels of these minerals increased in the biscuits. The weight, thickness, diameter, break strength and spread ratio of the biscuits increased with the level of tomato peel flour in the biscuits. The scores for all the sensory attributes decreased with the level of tomato peel flour in the biscuit. However, the biscuit containing $20 \%$ tomato peel flour was not significantly $(\mathrm{p}>0.05)$ different from the wheat flour biscuit in the sensory attributes assessed. The tomato peel flour could substitute $20 \%$ wheat flour in biscuit without adversely affecting the quality of the biscuit.
\end{abstract}

Keywords: Biscuit, Functionality, Phytochemicals, Sensory, Tomato peel.

Paper cited: Akubor, P.I. and Owuse, A.U. (2020). Chemical composition, functional and biscuit making properties of tomato peel flour. South Asian Journal of Food Technology and Environment, 6(1): 874884.

\section{Introduction}

Tomato (Lycopersicun esculentum $\mathrm{L}$ ) is a member of the family Solanaceae. Tomato is one of the most cultivated and consumed fruit vegetables in the world. In Nigeria, tomatoes are grown in large quantities. Nigeria was rated the $14^{\text {th }}$ largest producer of tomatoes in Africa with 2.3 million tons of tomatoes produced in 2014 (Ogundipe et al., 2012). However, 40-50\% of the tomatoes produced in Nigeria are lost due to poor handling and preservation practices (Ogundipe et al., 2012). Tomato is a source of vitamins C (20$25 \mathrm{mg} / 100 \mathrm{~g}$ ) and A, lycopene, minerals like iron $(5-12.2 \mathrm{mg} / \mathrm{kg}$, potassium $(2282-2668 \mathrm{mg} / \mathrm{kg})$ and trace amounts of carbohydrate and protein (Nwanekezi and Onyeali, 2005). The chemical composition, size, density as well as the seed, pulp and skin contents of tomato vary with 
variety (Nwanekezi and Onyeali, 2005; George et al ., 2004 ). Tomatoes are used to produce variety of products such as puree, ketchup, sauce, paste, juice, leather, powder among others. The pulp is usually the component of interest from which juice is extracted for the production of tomato paste. Tomato paste is used for the manufacture of other tomato products. However, about one third of tomato in the form of skin (peel) and seeds is discarded as waste during the processing of tomato products. These byproducts cause environmental pollution. However, tomato peels contain higher amounts of dietary fiber and antioxidants such as lycopene and phenolic compounds than the pulp (Del Valle et al., 2006). Lycopene which gives tomato its red color was reported to protect DNA and prevent heart diseases and cancer (Martinez-Valverde et al., 2002).

The high dietary fiber content of tomato peel and the bioactive compounds associated with the fibers make tomato peel an interesting ingredient for use in the food industry. The peels could be processed into flour and used for many applications. However, to determine the applications of tomato peel flour in food products, it is essential to determine its chemical composition and functional properties. Functional properties are the physicochemical characteristics which affect the behavior of food systems during processing, storage and consumption. The functional properties of tomato peel flour in food products would be determined among other factors by the food processing methods employed (Tosh and Yada, 2010). Thus, there is the need to evaluate the functionality of tomato peel flour in real food systems such as biscuits, bread etc.

Biscuit is consumed by all age groups due to its taste, crisp texture, ready to eat nature, good nutritional quality, availability in different forms and affordable cost (Akubor, 2016). Biscuits contain wheat flour, sugar, fat, water and salt as the main ingredients. Thus, they are high in carbohydrate, fat and calorie but low in fiber, vitamins and minerals which make them unhealthy for daily use. Biscuits are also low in phytochemicals which are associated with health benefits. However, the acceptability and long shelf life make biscuits suitable for fortification with nutritional components and bioactive compounds.

Therefore, the objectives of the study were to determine the chemical composition and functional properties of tomato peel flour and to evaluate the chemical composition, physical and sensory properties of biscuit supplemented with tomato peel flour.

\section{Materials and methods}

Source of materials: The tomato fruits were purchased from Vandeikya Market in Benue State, Nigeria. The wheat flour and the other ingredients were purchased from new Market in Wukari Township. The materials were stored in a refrigerator $\left(10^{\circ} \mathrm{C}\right)$ prior to use.

Preparation of ripe tomato peel flour: The ripe tomato fruits were washed in tap water and the spoilt ones were removed. The tomatoes were blanched in warm water $\left(80^{\circ} \mathrm{C}, 15 \mathrm{~min}\right)$ to facilitate the removal of the peel. The peels were removed manually, sun dried $\left(32^{\circ} \mathrm{C}\right)$ to constant weight, milled a hammer mill and sieved through a $425 \mu \mathrm{m}$ screen. The flour was packaged in high density polyethylene (HDPE) bags and stored at ambient temperature prior to use.

Flour blending: The wheat flour was sieved through a $425 \mu \mathrm{m}$ screen. The tomato peel flour was used to substitute 10, 20 and $30 \%$ of wheat flour in a food blender that was operated at full speed $(1200 \mathrm{rpm})$ for $10 \mathrm{~min}$. The flour was packaged in high density polyethylene (HDPE) bags and stored at ambient temperature prior to use. 
Preparation of biscuits: The biscuits were prepared using the straight dough method as described by Akubor (2016). The ingredients used were $49.5 \%, 20 \%$ margarine, $10 \%$ homogenized whole egg, 20\% sugar and $0.5 \%$ baking powder. The ingredients were weighed and thoroughly mixed manually. The wet ingredients were first mixed in a mixing bowl at evenly low speed for $5 \mathrm{~min}$. The dry ingredients were added and the mixing was continued at a high speed until uniform texture was obtained. The dough samples were then manually kneaded, molded, shaped and placed on the baking tray. The dough samples then weighed and baked in a thermostatically controlled baking oven at $170^{\circ} \mathrm{C}$ for 20 minutes. The biscuits produced were cooled to ambient temperature $\left(32^{\circ} \mathrm{C}\right)$ and packaged in polyethylene bags prior to analysis. The biscuits were produced in three replicates. The $100 \%$ wheat flour biscuit served as the control.

\section{Phyto-chemical, physical and sensory} evaluation of flours: The Phyto-chemical compositions (The total phenol, flavonoids and carotenoids contents) were determined as described by Okwu (2004). The proximate composition i.e. ash, moisture, fat, crude fiber and protein contents were determined as described by the AOAC (2010) methods. The carbohydrate content was calculated by difference. The total dietary fiber (TDF) and insoluble dietary fiber (IDF) contents were determined following the enzymatic-gravimetric methods 985.29 (AOAC, 2010). The soluble dietary fiber (SDF) content was calculated by subtracting the IDF from TDF. The physical evaluation of biscuits that is height and diameter of biscuit were determined using meter rule. The biscuit weight was determined using weighing balance. The spread ratio of biscuit was calculated as diameter height of biscuit. The break strength of biscuits was determined by subjecting the biscuit samples to various standard weights of 5, 10 and $50 \mathrm{~kg}$.
The sensory evaluation of the biscuits was conducted as described by Ihekoronye and Ngoddy (1985). A twenty (20) panel member randomly selected from the students and staff of the Department of Food Science and Technology, Federal University Wukari, Taraba State, Nigeria was used for the sensory evaluation of the biscuits. The sensory evaluation was carried out in a sensory evaluation laboratory under adequate lightening and ventilation in the mid morning (10 a.m). The biscuit samples were presented to the panelists in 3-digit coded plates. The order of presentation of biscuit samples to the panelists was randomized. The panelists were instructed to evaluate the coded samples for flavor, texture, color, taste and overall acceptability. Each sensory attribute was rated on a 9-point Hedonic scale $(1=$ disliked extremely and $9=$ liked extremely). The panelists were provided with distilled water to rinse their mouths in between evaluations.

Experimental Design and Statistical Analysis: The experiment was carried out in completely randomized design. The data were analyzed by one way analysis of variance using Statistical Package for Social Science software version 20, 2007. Means where significantly different were separated by the least significant difference (LSD) test. Significance was accepted at $\mathrm{p}<0.05$.

\section{Results and Discussion}

\section{Functional properties}

The functional properties of wheat flour and tomato peel are shown in Table 1. The water absorption capacity of wheat flour $(75.00 \%)$ was higher than that of tomato peel flour $(52.50 \%)$. The water absorption capacity of a dietary fiber source measures the amount of water retained by the fiber after subjected to centrifugation (Onimawo and Akubor, 2012). The water absorption capacity determined by centrifugation in the present study represented all the types of 
water( bound water to the hydrophilic polysaccharides, held within the fiber matrix, trapped within the cell wall lumen) associated with the fibers (Onimawo and Akubor,2012). Water absorption capacity represents the ability of a product to associate with water under conditions where water is limited (Onimawo and Akubor, 2012). The higher water absorption capacity of wheat flour could be attributed to the presence of higher amount of carbohydrates (starch) in the flour. The cellulose and insoluble hemicelluloses which were reported to be the main components of the dietary fiber in tomato flour, do not swell when mixed with water (Lecumberri et al., 2007). This could be one of the reasons for the water absorption capacity of tomato peel flour. Water soluble and insoluble portions (SDF and IDF) influence water absorption capacity of fiber source where fiber with high insoluble dietary fiber (IDF) portions has low water absorption capacity. The high proportion of IDF portions may have contributed to the low water absorption capacity of tomato peel flour relative to wheat flour. Water absorption capacity is an important hydration property of a fiber source that needs to be measured before incorporating the fiber source into food. Water absorption capacity is a critical function of protein in various food products like soups, dough and baked products (Okaka and Potter, 1997) where water absorption capacity aids the modification of texture and viscosity.

The wheat flour $(110.00 \%)$ had the higher oil absorption capacity than the tomato peel flour $(85.00 \%)$. Oil absorption capacity is another property of fiber rich ingredient that can be used for food product development. The ability of fiber to bind oil is related more to porosity of the fiber structure than affinity of the fiber molecule for oil (Reihaneh and Mehdi, 2010). The high moisture in the tomato peel flour (Table 3) may have reduced the oil absorption capacity of the flour as the pores were probably preoccupied by water. However, more complex mechanisms such as number of lipophilic sites, overall hydrophobicity and capillary attraction were shown to determine the variation in oil absorption capacity of fiber sources (Tosh and Yada, 2010). The wheat flour probably contained more lipophilic sites than the tomato peel flour. Food ingredient with high oil absorption capacity would be useful in stabilizing high -fat content food and emulsion by retaining fat (Tosh and Yada, 2010). Oil absorption capacity is important in flavor retention and product yield especially for cooked meat products that lose fat during cooking (Okaka and Potter, 1997). However, oil absorption capacity may interfere with lipid absorption in the gastrointestinal tract (Onimawo and Akubor, 2012).

The swelling capacities of wheat flour and tomato peel flour were 265.00 and 145.00, respectively. The swelling capacity of flours depends on particle size, variety and processing methods (Lecumberri et al., 2007). The amount of carbohydrate and protein, water availability, extent of starch damage also affect swelling capacity flour. The higher swelling capacity of the wheat flour may be due to the higher contents of carbohydrate and protein in addition to the higher water absorption capacity. Increase in water absorption capacity increases the swelling power.

However, the tomato peel flour $(0.85 \mathrm{~g})$ had higher bulk density than wheat flour $(0.68 \mathrm{~g})$. The low bulk density would be an advantage in the packaging of the flour and in the formulation of complementary foods (Akubor and Ukwuru, 2003).

\section{Phytochemical composition of flours and biscuits}

The Phytochemical composition of tomato peel flour, wheat flour and the biscuit supplemented with tomato peel flour is shown in 
Table 2. The flavonoids content of tomato peel flour $(676.04 \mathrm{mg} / 100 \mathrm{~g})$ was significantly $(\mathrm{p}<0.05)$ higher than those of the wheat flour $(1.20 \mathrm{~g} / 100 \mathrm{~g})$ and the biscuit $(211.35 \mathrm{mg} / 100 \mathrm{~g})$. Tomatoes are reported to be concentrated source of flavonoids with up to $98 \%$ of the total flavonoids contained in the tomato skin as conjugated forms of quercetin and kaempferol (Stewart et al., 2000). The high flavonoids content of the biscuit was contributed by the tomato peel flour. The decrease in the flavonoids content of the biscuit may be due to thermal oxidation following the baking process (Reihaneh and Mehdi, 2010). Flavanoids are antioxidants and were reported to lower cholesterol, inhibit tumor formation, decrease inflammation and protect against cancer, heart diseases among others (Onimawo and Akubor, 2012).

The phenol contents of the tomato peel flour, wheat flour and the biscuits were $1082.22 \mathrm{mg} / 100 \mathrm{~g}, 4.40 \mathrm{mg} / 100 \mathrm{~g}, 123.39 \mathrm{mg} / 100 \mathrm{~g}$, respectively. The total phenol content wheat content of wheat flour was lower than $10.13 \mathrm{mg} / 100 \mathrm{~g}$ reported for wheat flour by Hunt and Baker (1980). The peels of tomato are noted to be rich in lycopene and phenolic compounds (George et al., 2004). The baking might have caused thermal oxidation of phenol in the biscuit which caused the significant decrease in the phenol content. Phenolic compounds exhibit wide range of physiological properties such as antiallergenic, antiatherogenic, anti-inflammatory, anti-microbial, antioxidant, antithrombotic, cardioprotective, and vasodilator effects (Balasundram et al., 2006).

The carotenoids content of tomato peel flour $(69 \mathrm{mg} / 100 \mathrm{~g})$ was significantly $(\mathrm{p}<0.05)$ higher than that of the wheat flour $(0.48 \mathrm{mg} /$ $100 \mathrm{~g})$. The carotenoids content decreased to $12.5 \mathrm{mg} / 100 \mathrm{~g}$ in the biscuit. This could be due to the thermal processing of the biscuit in which heat might have liberated the carotenoids bound to the other food components. Studies have shown that lycopene from thermally processed tomato products is more bioavailable than lycopene from fresh tomatoes (Knoblich et al., 2005). The effects of processing and storage on carotenoid structure and stability are of interest for improper processing and storage (i.e., exposure to light and oxygen) may alter the ratio of lycopene isomers or degrade lycopene entirely (Singh and Goyal, 2008). Carotenoids play important roles in human nutrition and health. They are the precursors of vitamin A and are lipophilic antioxidants with strong anti-cancer properties (Basu and Imrhan, 2007; Rao and Agarwal, 1999).

\section{Proximate composition of flours and biscuit}

Table 3 presents the proximate composition of wheat flour, tomato peel flour and the biscuit supplemented with tomato peel flour. The wheat flour had moisture of $8.15 \%$ which was lower than the $9.20 \%$ for the tomato peel flour. The moisture content of the biscuit (7.70\%) was lower than those of the flours. Akubor and Ukwuru (2003) reported that moisture contents of biscuits vary with the type of biscuit where cream crackers had $4.3 \%$ moisture content while digestive had $4.5 \%$. The ash, fat, protein and fiber contents of tomato peel flour were higher than those of wheat flour. These constituents increased in the biscuit relative to wheat flour due to addition effect. However, the carbohydrate content of the tomato peel flour was lower than that of wheat flour. Ash is an indicative of the amount of mineral in any food sample. The fat content of tomato peel flour was slightly higher $(1.29 \%)$ than that of wheat flour $(1.08 \%)$. The high fat content of the biscuit may be due to the contribution of fat from the ingredients (margarine, baking fat and egg) used in the preparation of the biscuit. The low fat content of the products would not encourage the development of rancidity during storage (Ihekoronye and Ngoddy, 1985). Nwanekezi and Onyeali (2005) had reported that tomato peel has 
low crude protein of $13.3 \%$. The protein content of the biscuit was higher than that of the peel flour. This makes tomato peel a good protein supplement. The wheat flour contained $1.21 \%$ of crude fiber. The crude fiber content decreased from $2.93 \%$ in the tomato peel flour to 2.51 in the biscuit. The high level of crude fiber of biscuit could be of potential usefulness. The therapeutic effects of fiber in the prevention of heart diseases, colon cancer and diabetes and their role in the treatment of digestive disorders (diverticulosis) and constipation are widely documented (Anderson et al.,1994; Larrauri, 1999). The carbohydrate contents of tomato peel flour, wheat flour and biscuit were 64.93, 76.45 and $59.57 \%$ respectively. The lower carbohydrate content of the biscuit $(59.97 \%)$ could be attributed to the low content of carbohydrate in tomato peel flour.

\section{Fiber composition}

The total dietary fiber (TDF) content of the tomato peel flour was $85.56 \%$ which was mostly contributed by insoluble dietary fiber (IDF) $(70.25 \%)$ given in Table 4 . The soluble dietary fiber (SDF) content of tomato peel flour was $15.31 \%$. The blanching of the tomatoes in hot water which enhanced the removal of the skin probably caused the leaching of soluble dietary fibers. The TDF content of the tomato peel flour was above $50 \mathrm{~g} / 100 \mathrm{~g}$ required for food to be regarded as fiber rich (Larrauri, 1999). For certain food applications, the dietary fiber source should have a balance of soluble and insoluble fractions. For the tomato peel flour, the SDF/IDF ratio was 4.56. The high IDF content of tomato peel flour and biscuit would be of significance in food products. The ingestion of IDF causes sensation of satiety, since it absorbs water and increases bolus size. It also increases the volume and weight of the faecal bolus, promoting improved functioning of the digestive system and preventing disorders such as constipation, haemorrhoids and colon cancer $(\mathrm{Ku}$ and Mun, 2008) .Soluble fibers, however, regulate blood cholesterol and lower blood glucose level $(\mathrm{Ku}$ and Mun, 2008).

\section{Mineral composition}

The mineral composition of tomato peel flour, wheat flour and the biscuit supplemented with tomato peel flour are presented in Table 5. The tomato peel flour contained significantly $(\mathrm{p}<0.05)$ higher amounts of $\mathrm{Na}, \mathrm{K}, \mathrm{Ca}, \mathrm{Mg}, \mathrm{Fe}$ and $\mathrm{Zn}$ than the wheat flour and the biscuit. The levels of these minerals increased with the levels of tomato peel flour in the biscuits probably due to addition effect since tomato peel flour was higher in these minerals. The $\mathrm{Na}$ content of wheat flour was $3.6 \mathrm{mg} / 100 \mathrm{~g}$. The $\mathrm{Na}$ content decreased from $72 \mathrm{mg} / 100 \mathrm{~g}$ in the tomato peel flour to $56.02 \mathrm{mg} / 100 \mathrm{~g}$ in the biscuit. The tomato peel flour contained significantly lower amount potassium $(112.3 \mathrm{mg} / 100 \mathrm{~g})$ than the wheat flour (317 mg / 100g) and the biscuit (2.90.9 mg / $100 \mathrm{~g}$ ). The high $\mathrm{K} / \mathrm{Na}$ ratio in these products is desirable because an average human diet is low in $\mathrm{K}$ but high in $\mathrm{Na}$ (ADA, 2002). Sodium and potassium influence osmotic pressure and contribute to normal $\mathrm{pH}$ equilibrium (ADA, 2002). The American Dietetic Association (ADA) (2000) recommended that the amount of sodium in the diet should be limited since sodium increases blood pressure and the retention of body fluid. The tomato peel flour and the biscuit are low sodium foods based on the ADA classification where foods that contain $140 \mathrm{mg} / 100 \mathrm{~g}$ of sodium or less are low sodium foods (ADA, 2002). The ADA (2002) recommended an average daily intake of less than $200 \mathrm{mg} /$ day of sodium .The calcium contents of the tomato peel flour and the biscuit were 142.3 and $122.5 \mathrm{mg} / 100 \mathrm{~g}$, respectively. These byproducts could be classified as a source of calcium for adults (ADA, 2002). Calcium is an important constituent of the body where it is used among other functions for bone formation (Belitz and Grosch, 1999). The magnesium contents of the tomato peel flour and the biscuit 155.4 and 
$163.9 \mathrm{mg} / 100 \mathrm{~g}$, respectively. A portion of $100 \mathrm{~g}$ of these products may provide more than $15 \%$ of the magnesium dietary recommendation intake for people of any age or gender (ADA, 2002). Thus, they are would be classified as a source of' magnesium (ADA, 2002). Magnesium is present in the mitochondria and other enzymes important in energy transfer (Cerklewski, 1991). Magnesium in an activator of enzyme systems which maintains electrical potential in nerves (Cerklewski, 1991). Some minerals are components of antioxidants enzymes. Superoxide dismutase depends on $\mathrm{Mn}, \mathrm{Cu}$ and $\mathrm{Zn}$; catalase depends on $\mathrm{Fe}$ and glutathione peroxidase on $\mathrm{Se}$ (Cerklewski, 1991)). Copper and iron are required in mammalian nutrition to prevent anemia (Cerklewski, 1991). The iron and zinc contents of the biscuit were higher than those of the wheat flour but lower than those of the tomato peel flour. The DRI for $\mathrm{Zn}$ is $7 \mathrm{mg} /$ day for adult, respectively (ADA, 2002). Hence, the TPF and biscuit $(100 \mathrm{~g})$ can be considered rich source of Zn.

\section{Physical properties of the biscuits}

The physical properties of the biscuits supplemented with tomato peel flour are presented in Table 6. The weight of the $100 \%$ wheat flour biscuit was $9.35 \mathrm{~g}$. The weight decreased from $7.65 \mathrm{~g}$ for the biscuit containing $10 \%$ tomato peel flour (TPF) to $6.82 \mathrm{~g}$ for the biscuit containing $30 \%$ TPF. The higher weight of the $100 \%$ wheat flour biscuit may be due to the higher water absorption capacity of the wheat flour (Table1). The wheat and tomato peel flour blends probably retained less water and oil than the wheat flour during the baking process. The wheat flour biscuit also had higher thickness, diameter, break strength and spread ratio than the biscuit containing TPF. These properties of the biscuit decreased with level of TPF in the biscuit probably due to dilution of gluten protein. Gluten is the skeleton of wheat dough, which gives it elastic structure. Replacement of wheat flour with fiber rich ingredients affects gluten network formation by gluten dilution, competition for water and /or mechanical disruption of the gluten network. Hence, the decrease in the physical properties of the biscuits with the level of the tomato peels flour. During dough development, gluten which conifers gas retention properties to wheat flour dough, becomes extensive and strong (Belitz and Grosch, 1999). This allows the dough to rise and also prevent easy escape of the gas during baking (Belitz and Grosch, 1999)). This property was reduced in the composite flour dough The decrease in the thickness, diameter and spread ratio of the biscuits may be due to the high water absorption capacity of the wheat flour. This capacity increased the viscosity of the dough and decreases the thickness, diameter and spread ratio of biscuit (Akubor, 2016).

Table 1: Functional properties of wheat flour and tomato peel flour

\begin{tabular}{|l|c|c|}
\hline Samples & Wheat flour & Tomato peel flour \\
\hline Water absorption capacity (\%) & $75.04^{\mathrm{b}} \pm 0.52$ & $52.500^{\mathrm{a}} \pm 0.33$ \\
Oil absorption capacity (\%) & $110.07^{\mathrm{b}} \pm 0.14$ & $85.00 \mathrm{a} \pm 0.71$ \\
Swelling capacity (\%) & $265.00^{\mathrm{b}} \pm 1.20$ & $145.00^{\mathrm{a}} \pm 0.07$ \\
Bulk density $\left(\mathrm{g} / \mathrm{cm}^{3}\right)$ & $0.68^{\mathrm{a}} \pm 0.02$ & $0.85^{\mathrm{b}} \pm 0.03$ \\
\hline
\end{tabular}

Values are means \pm SD of 3 replications. Means within a column with the same superscript were not significantly different $(p<0.05)$ 
Table 2: Phytochemical composition (mg/100g) of tomato peel flour, wheat flour and the biscuit supplemented with tomato peel flour

\begin{tabular}{|l|c|c|c|}
\hline Phytochemical & Tomato peel flour & Wheat flour & Biscuit \\
\hline Flavonoids & $676.05^{\mathrm{c}} \pm 0.89$ & $1.20^{\mathrm{b}} \pm 0.05$ & $211.35^{\mathrm{a}} \pm 0.93$ \\
\hline Phenols & $1082.22^{\mathrm{a}} \pm 0.34$ & $4.4^{\mathrm{c}} \pm 0.87$ & $123.39^{\mathrm{b}} \pm 0.23$ \\
\hline Carotenoids & $69^{\mathrm{b}} \pm 0.74$ & $0.48^{\mathrm{a}} \pm 0.12$ & $12.5^{\mathrm{c}} \pm 0.92$ \\
\hline
\end{tabular}

Values are means \pm SD of 3 replicates. Means within a row with the same superscript were not significantly different (p>0.05). The biscuit contained $20 \%$ tomato peel flour.

Table 3: Proximate composition (\%) of flours and biscuit supplemented with tomato peel flour.

\begin{tabular}{|l|c|c|c|}
\hline Proximate composition & Tomato peel flour & Wheat flour & Biscuit \\
\hline Moisture & $9.20^{\mathrm{b}} \pm 1.00$ & $8.15^{\mathrm{a}} \pm 1.00$ & $7.70^{\mathrm{b}} \pm 1.00$ \\
Ash & $8.35^{\mathrm{c}} \pm 1.00$ & $1.26^{\mathrm{a}} \pm 1.00$ & $4.85^{\mathrm{b}} \pm 1.00$ \\
Fats & $1.29^{\mathrm{b}} \pm 1.00$ & $1.08^{\mathrm{a}} \pm 1.00$ & $11.02^{\mathrm{a}} \pm 1.00$ \\
Protein & $12.26^{\mathrm{a}} \pm 1.00$ & $10.29^{\mathrm{a}} \pm 1.00$ & $11.82^{\mathrm{b}} \pm 1.00$ \\
Fibre & $2.93^{\mathrm{c}} \pm 1.00$ & $1.21^{\mathrm{a}} \pm 1.00$ & $2.51^{\mathrm{b}} \pm 1.00$ \\
Carbohydrate & $65.97^{\mathrm{b}} \pm 1.00$ & $78.81^{\mathrm{c}} \pm 1.00$ & $62.10^{\mathrm{a}} \pm 1.00$ \\
\hline
\end{tabular}

Values are means \pm SD of 3 replicates. Means within a row with the same superscript were not significantly different (p>0.05). The biscuit contained $20 \%$ tomato peel flour.

Table 4: Dietary fiber composition of tomato peel flour, wheat flour and the biscuit supplemented with tomato peel flour

\begin{tabular}{|l|c|c|c|}
\hline Composition (\%) & Tomato peel flour & Wheat flour & Biscuit \\
\hline Crude fiber & $2.93^{\mathrm{a}}$ & $1.21^{\mathrm{b}}$ & $2.51^{\mathrm{a}}$ \\
Total dietary fiber & $85.56^{\mathrm{a}}$ & $34.80^{\mathrm{c}}$ & $72.01^{\mathrm{b}}$ \\
Insoluble dietary fiber & $70.25^{\mathrm{a}}$ & $23.35^{\mathrm{c}}$ & $58.94^{\mathrm{b}}$ \\
Soluble dietary fiber & $15.31^{\mathrm{a}}$ & $11.45^{\mathrm{c}}$ & $13.07^{\mathrm{b}}$ \\
\hline
\end{tabular}

Values are means \pm SD of 3 replicates. Means within a row with the same superscript were not significantly different (p>0.05). The biscuit contained $20 \%$ tomato peel flour.

Table 5: Mineral composition (mg/100g) of tomato peel flour, wheat flour and the biscuit supplemented with tomato peel flour

\begin{tabular}{|c|c|c|c|}
\hline Mineral & Tomato peel flour & Wheat flour & Biscuit \\
\hline $\mathrm{Na}$ & 72.0 & 3.6 & 56.02 \\
$\mathrm{~K}$ & 112.3 & 317.0 & 290.9 \\
$\mathrm{Ca}$ & 142.3 & 28.1 & 122.5 \\
$\mathrm{Mg}$ & 155.4 & 141.0 & 163.9 \\
$\mathrm{Fe}$ & 2.15 & 1.29 & 1.85 \\
$\mathrm{Zn}$ & 2.89 & 1.61 & 2.41 \\
\hline \multicolumn{2}{|l|}{ Values are means \pm SD of 3 replicates. Means within a row with the same superscript were not significantly different (p>0.05). The biscuit } \\
contained 20\% tomato peel flour.
\end{tabular}

Table 6: Physical properties of biscuits supplemented with tomato peel flour

\begin{tabular}{|l|c|c|c|c|}
\hline \multirow{2}{*}{ Physical properties } & \multicolumn{4}{|c|}{ WF : TPF } \\
\cline { 2 - 5 } & $\mathbf{1 0 0 : 0}$ & $\mathbf{9 0 : 1 0}$ & $\mathbf{8 0 : 2 0}$ & $\mathbf{7 0 : 3 0}$ \\
\hline Weight & $9.35^{\mathrm{d}} \pm 1.00$ & $7.65^{\mathrm{b}} \pm 1.00$ & $7.37^{\mathrm{a}} \pm 1.00$ & $6.82^{\mathrm{a}} \pm 1.00$ \\
Thickness & $1.04^{\mathrm{c}} \pm 1.00$ & $0.87^{\mathrm{b}} \pm 0.07$ & $0.81^{\mathrm{b}} \pm 0.74$ & $0.56^{\mathrm{a}} \pm 1.00$ \\
Diameter & $5.30^{\mathrm{b}} \pm 0.13$ & $5.05^{\mathrm{ab}} \pm 0.13$ & $5.05^{\mathrm{a}} \pm 0.32$ & $4.90^{\mathrm{a}} \pm 0.32$ \\
Break strength & $1825.00^{\mathrm{d}} \pm 1.00$ & $1625.00^{\mathrm{c}} \pm 1.00$ & $1480.00^{\mathrm{b}} \pm 1.00$ & $584.50^{\mathrm{a}} \pm 100$ \\
Spread ratio & $8.93^{\mathrm{d}} \pm 1.00$ & $5.98^{\mathrm{c}} \pm 1.00$ & $5.79^{\mathrm{b}} \pm 1.00$ & $5.09^{\mathrm{a}} \pm 1.00$ \\
\hline
\end{tabular}

Values are means \pm SD of 3 replicates. Means within a row with the same superscript were not significantly different (p>0.05). The biscuit contained $20 \%$ tomato peel flour. 


\section{Sensory properties of biscuit}

The mean scores of the biscuits supplemented with tomato peel flour are shown in Table 7. The scores for all the sensory attributes of the biscuit containing tomato peel flour except flavor were significantly $(\mathrm{p}<0.05)$ lower than those of $100 \%$ wheat flour biscuit. The scores for all the sensory attributes decreased with the level of the tomato peel flour in the biscuits. The scores for color decreased from 7.40 for the biscuit containing $10 \%$ tomato peel flour to 6.60 for the biscuit containing 30\% tomato peel flour. This could be due to the red color of tomato peel which turned dark during baking. The decrease in the scores for texture may be due to the increase in fiber contents of the biscuit following the addition of tomato peel flour. Increase in fiber content of bread resulted in bread with hard texture (Okaka and Potter, 1997). The decrease in the scores for taste might be due to the spicy and sour after taste of tomato peel flour. The scores for flavor of the biscuit decreased with the level of TPF in the biscuit. The characteristic tomato flavor is produced by the complex interaction of the volatile and non-volatile components (Periago et al., 2009). The decreased in the flavor of the biscuit was due to the loss of the volatile flavor compounds in the tomato peel flour during the drying and baking processes. The scores for the overall acceptability of the biscuits containing tomato peel flour were not significantly $(\mathrm{p}>0.05)$ different from those of the $100 \%$ wheat flour biscuit.

Table 7: Mean sensory scores of biscuits supplemented with tomato peel flour

\begin{tabular}{|l|c|c|c|c|}
\hline \multirow{2}{*}{ Sensory Parameters } & \multicolumn{4}{|c|}{ WF:TPF } \\
\cline { 2 - 5 } & $\mathbf{1 0 0 : 0}$ & $\mathbf{9 0 : 1 0}$ & $\mathbf{8 0 : 2 0}$ & $\mathbf{7 0 : 3 0}$ \\
\hline Color & $8.20^{\mathrm{b}} \pm 0.14$ & $7.40^{\mathrm{ab}} \pm 0.14$ & $7.00^{\mathrm{a}} \pm 0.17$ & $6.60^{\mathrm{a}} \pm 0.11$ \\
Textur & $7.70^{\mathrm{c}} \pm 0.24$ & $7.10^{\mathrm{b}} \pm 0.32$ & $6.60^{\mathrm{ab}} \pm 0.32$ & $6.00^{\mathrm{a}} \pm 0.21$ \\
Taste & $7.60^{\mathrm{b}} \pm 0.41$ & $7.60^{\mathrm{b}} \pm 0.41$ & $7.10^{\mathrm{ab}} \pm 0.11$ & $6.20^{\mathrm{a}} \pm 0.11$ \\
Flavor & $7.40^{\mathrm{a}} \pm 0.54$ & $7.30^{\mathrm{a}} \pm 0.54$ & $7.30^{\mathrm{a}} \pm 0.54$ & $7.10^{\mathrm{a}} \pm 0.54$ \\
Overall acceptability & $7.80^{\mathrm{a}} \pm 0.20$ & $7.60^{\mathrm{a}} \pm 0.20$ & $7.10^{\mathrm{a}} \pm 0.20$ & $7.10^{\mathrm{a}} \pm 0.20$ \\
\hline
\end{tabular}

Values are means \pm SD of 3 replicates. Means within a row with the same superscript were not significantly different (p>0.05). The biscuit contained $20 \%$ tomato peel flour.

\section{Conclusion}

Based on the result of this study, it may be concluded that ripe tomato peel flour possesses functional properties for various food applications. The ripe tomato peel flour could be used to substitute $20 \%$ of wheat flour in biscuit without adversely affecting the chemical composition, physical and sensory properties of the biscuit.

\section{Recommendation}

Based on the results of this study, it is recommended that:

i. Ripe tomato peel flour should be incorporated into wheat flour at $20 \%$ level for the production of biscuit.

ii. The storage stability of tomato peel flour and biscuit containing tomato peel flour should be determined. iii. The performance of ripe tomato peel flour in other food systems should be investigated.

\section{References}

1. A.O.A.C (2010). Official Method of Analysis. Association of Analytical Chemists. Edition, Washington, D.C.

2. ADA (2002). Evidence based nutrition principles and recommendations for the treatment and prevention of diabetes and related complications. Diabetes Care, 25(1): 550-560

3. Akubor, P.I. (2016). Chemical composition, physical and sensory properties of biscuits supplemented with cashew pomace flour. NSUK Journal of Science and Technology, 6(2): 138- 141 
Peter Isah Akubor and Abubakar Usman Owuse

4. Akubor, P.I. and Ukwuru, M.U. (2003). Functional properties and biscuit making potential of soybean and cassava flour blends. Plant Foods for Human Nutrition, 58:1-12

5. Akubor, P.I., Yusuf, D., and Obiegbuna, J.E. (2013). Proximate composition and functional properties of flours from the kernel of African star apple (Chyrysophyllual albidum) International Journal of Agricultural Policy and Research, 1(3): 062-066

6. Anderson, J.W., Baird, P. and Davis, P.H. (2009). Health benefits of dietary fibre. Nutrition Review, 67(4): 188-205

7. Balasundram, N., Sundram, K. and Samman, S. (2006). Phenolic compounds in plant and agri-industrial by-products: Antioxidant activity, occurrence, and potential uses. Food Chemistry, 99:191203.

8. Basu, A. and Imrhan, V. (2007). Tomatoes versus lycopene in oxidative stress carcinogenesis: conclusions from clinical trials. European Journal Clinical Nutrition, 61: 295-303

9. Belitz, H., and Grosch, W. (1999). Food Chemistry, $2{ }^{\text {nd }} E d n$, Belin, Springer

10. Cerklewski, F. (1991): Hand book of nutritionally essential minerals, Mercel Dehher, Inc New York, USA, and Pp 583 602.

11. Del Valle, M., Câmara, M.M. and Torija, M. E. (2006). Chemical characterization of tomato pomace. Journal of the Science of Food and Agriculture, 86: 1232-1236.

12. George, B., Kaur, C., Khurdiya, D.S., and Kapoor, H.C. (2004). Antioxidants in tomato (Lycopersium esculentum) as a function of genotype. Food Chemistry, 845851.

13. Hunt, G.M. and Baker, E.A. (1980). Phenolic constituents of tomato fruit cuticles. Phytochemistry, 19: 1415-1419.

14. Ihekoronye, I.A., and Ngoddy, P.O.(1985). Integrated Food Science and Technology for the Tropics, Macmillian Publishers. pp. 213-267

15. Knoblich, M., Anderson, B., and Latshaw, D. (2005). Analyses of tomato peel and seed byproducts and their use as a source of carotenoids. Journal of the Science of Food and Agriculture, 85: 1166-1170.

16. $\mathrm{Ku}, \mathrm{C.S}$. and Mun, S.P. (2008). Optimization of the extraction of anthocyanin from Bokbuna (Rubus cureanus) produced during the traditional wine processing and the characteristics of the extracts. Bioresource Technology, 99: 8325-8330

17. Larrauri, J.A. (1999). New approaches in the preparation of powder from fruit by products. Trends in Food Science and Technology, 10(1): 3-8

18. Lecumberri, E., Mateos, R., IzquierdoPulido, M., Rupérez, P., Goya, L. and Bravo, L. (2007). Dietary fibre composition, antioxidant capacity and physico-chemical properties of a fibre-rich product from cocoa (Theobroma cacao L.). Food Chemistry, 104: 948-954.

19. Martínez-Valverde, I., Periago, M.J., Provan, G. and Chesson, A. (2002). Phenolic compounds, lycopene and antioxidant activity in commercial varieties of tomato (Lycopersicum esculentum). Journal of the Science of Food and Agriculture, 82:323-330.

20. Nwanekezi, E.C. and Onyali, N.O.(2005). Effect of chemical preservation on the shelf life of bottled intermediate moisture tomato paste stored at ambient temperature. Nigerian Food Journal, 25:183-193

21. Ogundipe, F.O., Bamidele, F.A., AdebayoOyetoro, A.O., Ogundipe, O.O. and Tajudeen, O.K. (2012). Incidence of bacteria with potential public health implications in raw Lycoperscion esculentum (Tomato) sold in Lagos Statte, Nigeria. Nigerian Food Journal, 30(2): 106113.

22. Okaka, J.C. and Potter, N.N. (1997). Functional properties of cowpea wheat flour blends in bread making. Journal of Food Science, 42: 828-833.

23. Okwu, D.E. (2004). Phytochemical and vitamin contents of indigenous 883 of Southeast Nigerian. Journal of Sustainable Agriculture and Environment, 6: 30-37. 
24. Onimawo I.A and Akubor, P.I.(2012). Food chemistry (Integrated approach with biochemical background). 2nd edn. Joytal Printing Press, Agbowo, Ibadan, Nigeria

25. Periago, M.J., García-Alonso, J., Jacob, K., Olivares, A.B., Bernal, A.J. and Iniesta, M.D. (2009). Bioactive compounds, folates and antioxidant properties of tomatoes (Lycopersicume sculentum) during vine ripening. International Journal of Food Science and Nutrition, 60(8): 694-708.

26. Rao, A.V. and Agarwal, S. (1999). Role of lycopene as antioxidant carotenoid in the prevention of chronic diseases: A review. Nutrition Research, 19: 305-323.

27. Reihaneh, A.G. and Mdehi, G.D. (2010). Studies on Physicochemical properties of tomato powder as affected by different dehydration methods and pretreatments.
World Academy of $\quad$ Science Engineering and Technology, 69: 117-129

28. Singh, P. and Goyal. G.K. (2008). Dietary lycopene: its properties and anticarcinogenic effects. Compressive Review in Food Science and Food Safety, 7: 255-270

29. Stewart, A.J., Bozonnet, S., Mullen, W., Jenkins, G.I., Lean, M.E.J. and Crozier, A. (2000). Occurrence of flavonols in tomatoes and tomato-based products. Journal Agriculture Food Chemistry, 48: 2663-2669.

30. Tosh, S. M. and Yada, S. (2010). Dietary fibres in pulse seeds and fractions: Characterization, functional attributes, and applications. Food Research International, 43: 450-460.

\begin{tabular}{|ll|}
\hline Received & : March, 2020 \\
Revised & : April, 2020 \\
Published & : June, 2020 \\
\hline
\end{tabular}

